ISSN 2620-6760, Vol.4, No. 1, April 2021

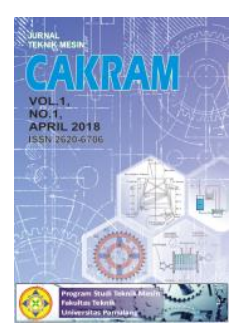

\title{
PENGARUH PENAMBAHAN CAMPURAN ABU BATOK KELAPA TERHADAP KUAT TEKAN, KEKERASAN DAN DAYA SERAP AIR PADA PEMBUATAN BETON
}

\author{
Fifit Astuti, Aliffudin Al Irfan \\ Program Studi Teknik Mesin Fakultas Teknik Universitas Pamulang \\ E-mail : dosen01140@unpam.ac.id
}

Masuk : 4 Maret 2021

Direvisi : 29 Maret 2021

Disetujui : 5 April 2021

\begin{abstract}
Abstrak: Beton merupakan campuran antara semen, agregat halus, agregat kasar, dan air sehingga membentuk massa padat. Kualitas benton tergantung pada bahan dasar penyusunnya, cara pelaksanaan dan perawatan beton. Penelitian ini bertujuan untuk mengetahui pengaruh penambahan abu tempurung kelapa tersebut terhadap daya serap air, kuat tekan dan kekerasan pada beton. Pada pengujian ini bahan tambahan abu temburung kelapa dalam pembuatan beton dengan variasi penambahan 0 gram, 3 gram, 5 gram, 7 gram, 9 gram dan 11 gram. Jumlah bahan uji yang dibuat sebanyak 5 buah pada setiap sampel. Pengujian dilaksanakan pada umur beton 21 hari. Berdasarkan penelitian diperoleh bahwa semakin banyak kandungan abu tempurung pada beton, daya serap air beton semakin meningkat. Hasil uji kuat tekan dan kekerasan pada beton diperoleh nilai optimal dengan penambahan abu tempurung kelapa dengan porsentase 5 gram dengan nilai rata-rata uji kuat tekan $31,25 \mathrm{~kg} / \mathrm{cm}^{2}$ dan nilai rata-rata uji kekerasan diperoleh 400 Brinnel. Hasil ini lebih baik dibandingakan beton normal yang memperoleh nilai uji tekan $22,5 \mathrm{~kg} / \mathrm{cm}^{2}$ dan hasil nilai rata-rata kekerasan yang diperoleh 50 HD. Pada penambahan abu batok kelapa porsentase melebihi 5 gram menyebabkan nilai uji tekan dan kekerasan akan mengalami penurunan.
\end{abstract}

Kata kunci : abu batok kelapa, beton, kuat tekan, kekerasan, daya serap air

Abstract: Concrete is a mixture of cement, fine aggregate, coarse aggregate, and water to form a solid mass. The quality of concrete depends on the basic ingredients of its constituents, the way it is carried out and the concrete is treated. This study aims to determine the effect of adding coconut shell ash on water absorption, compressive strength and hardness of concrete. In this test, additional material of coconut clay ash in the manufacture of concrete with the addition of variations of 0 grams, 3 grams, 5 grams, 7 grams, 9 grams and 11 grams. The number of test materials made of 5 pieces in each sample. The test is carried out at the age of 21 days of concrete. Based on the research, it was found that the more shell ash content in the concrete, the water absorption capacity of the concrete increased. The results of the compressive strength and hardness test in concrete obtained the optimal value by adding coconut shell ash with a percentage of 5 grams with an average compressive strength test value of 31.25 $\mathrm{kg} / \mathrm{cm}^{2}$ and an average value of hardness test obtained $56.1 \mathrm{HD}$. This result is better than normal concrete which has a compressive test value of $22.5 \mathrm{~kg} / \mathrm{cm}^{2}$ and the average hardness value obtained is $50 \mathrm{HD}$. Adding coconut shell ash to a percentage of more than 5 grams causes the compressive and hardness test values to decrease.

Keywords: coconut shell ash, concrete, compressive strength, hardness, water absorption 


\section{PENDAHULUAN}

Perkembangan kontruksi di Indonesia saat ini semakin meningkat. Beton merupakan material utama dalam bidang kontruksi. Beton juga merupakan suatu komposit dari bahan batuan yang direkatkan oleh bahan ikat [1]. Seiring peningkatan pembangunan konstruksi beton maka permintaan material pengikat dan pengisi beton meningkat. Semen merupakan bahan pengikat beton. Konsumsi semen dalam negeri mengalami kenaikan hingga 29,2\% dibandingkan Juni 2019 [2]. Kebutuhan permintaan semen yang tinggi tidak diimbangi dengan adanya produksi semen yang berimbang sehingga Indonesia masih menggunakan semen impor untuk memenuhi kebutuhan pembangunan di Indonesia.

Penggunaan semen potland dalam proses pembuatan beton untuk konstruksi dapat merusak lingkungan. Dalam memproduksi 1 ton semen potland itu akan menghasilkan kurang lebih 1 ton karbondioksida ke atmosfer [3]. Hal ini menyebabkan tidak ramah lingkungan dalam pengembangan lingkungan yang berkelanjutan. Oleh karena itu, diperlukan material tambahan yang dapat meningkatkan kualitas beton dan mengurangi pemakaian semen.

Limbah batok kelapa merupakan limbah yang mudah ditemui dimana-mana misalnya di pasar, dapur, pantai dan lainlain. Produksi kelapa di Indonesia per tahun yakni sebesar 12.915 milyar butir atau 24\% produksi dunia [4]. Pemanfaatan limbah batok kelapa di Indonesia masih sangat terbatas berbanding terbalik dengan jumlahnya yang sangat banyak dan melimpah. Limbah batok kelapa dapat dimanfaatkan menjadi campuran dalam pembuatan beton dengan dilakukan proses pembakaran terlebih dahulu. Hal ini bertujuan meningkatkan nilai guna limbah batok kelapa dalam proses pembuatan beton.

Tabel 1. Kandungan Oksida Pada Abu Batok Kelapa [5]

\begin{tabular}{|c|c|}
\hline Kandungan & Kadar (\%) \\
\hline $\mathrm{SiO}_{2}$ & 37,97 \\
\hline $\mathrm{Al}_{2} \mathrm{O}_{3}$ & 24,12 \\
\hline $\mathrm{Fe}_{2} \mathrm{O}_{3}$ & 15,48 \\
\hline $\mathrm{CaO}$ & 4,98 \\
\hline $\mathrm{MgO}$ & 1,89 \\
\hline $\mathrm{MnO}$ & 0,81 \\
\hline $\mathrm{Na} 2 \mathrm{O}$ & 0,95 \\
\hline $\mathrm{K} 2 \mathrm{O}$ & 0,83 \\
\hline $\mathrm{P}_{2} \mathrm{O}_{5}$ & 0,32 \\
\hline $\mathrm{SO}_{3}$ & 0,71 \\
\hline $\mathrm{LOI}$ & 11,94 \\
\hline
\end{tabular}

Pada abu hasil pembakaran batok kelapa terkandung campuran dari berbagai oksida mineral yaitu natrium oksida $\left(\mathrm{Na}_{2} \mathrm{O}\right)$, kalium Oksida $\left(\mathrm{K}_{2} \mathrm{O}\right)$, Magnesium Oksida $(\mathrm{MgO})$, besi oksida $\left(\mathrm{Fe}_{2} \mathrm{O}_{3}\right)$, silikon dioksida $\left(\mathrm{SiO}_{2}\right)$ dan beberapa senyawa lainnya. Unsur yang terkandung dalam abu dan memiliki efektifitas senyawa penyerap adalah senyawa silikon dioksida $\left(\mathrm{SiO}_{2}\right)$. Kandungan $\mathrm{SiO}_{2}$ pada limbah batok kelapa sekitar 37,97\%[5]. Dengan kandungan ini, limbah batok kelapa bersifat pozzolan yang dapat digunakan sebagai bahan pengisi beton. Oleh karena itu, perlu adanya penelitian pengaruh penambahan limbah batok kelapa terhadap kualitas beton. Penelitian ini bertujuan untuk mengetahui pengaruh komposisi beton terhadap uji kuat tekan, kekerasan dan daya serap air beton.

\section{METODOLOGI}

Pada penelitian ini metode yang digunakan adalah metode eksperimen membandingkan beton normal dengan beton campuran limbah batok kelapa. Tahap persiapan penelitian dilakukan dengan menyiapkan semua alat dan bahan yang dibutuhkan. Alat-alat yang di gunakan dalam pengujian ini adalah timbangan, cetakan dari paralon, sendok semen atau cungkir, garagaji pipa/besi, jangka sorong, gelas mili untuk air, mistar dan alat pendukung yang lainnya. Bahan yang digunakan yaitu semen, pasir (agregat halus), batu split kecil (agregat kasar), air, limbah batok kelapa. Berikut diagram alir penelitian ini. 
Fifit Astuti, Alifuddin Al Irfan, Pengaruh Penambahan Campuran Abu Batok Kelapa Terhadap Kuat Tekan, Kekerasan dan Daya Serap Air Pada Pembuatan Beton

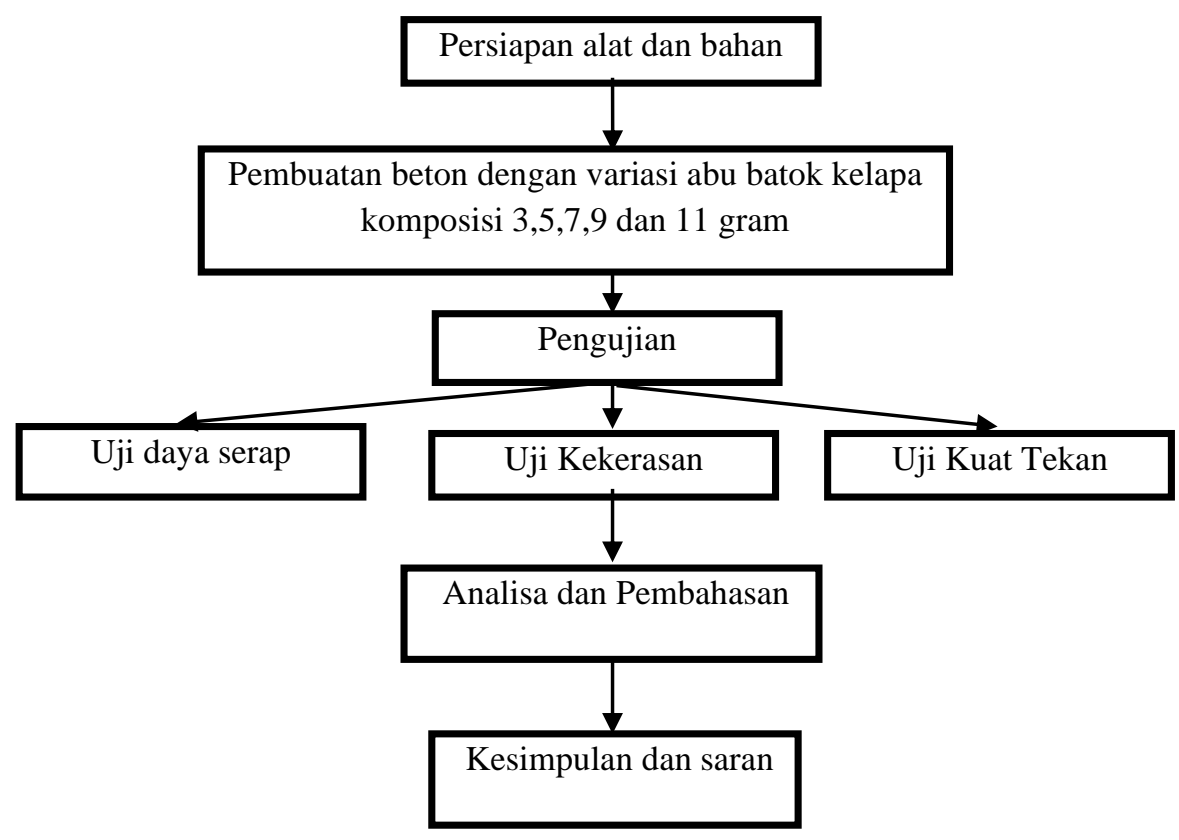

Gambar 1. Diagram Alir Penelitian

Tahap perencanaan campuran adukan beton yaitu menghitung kebutuhan bahan dengan menggunakan tabel mix design awal dan menghitung volume total bahan yang dibutuhkan untuk pembuatan benda uji beton. Tahap pelaksanaan berupa persiapan cetakan beton, pencampuran bahan adukan beton seperti Tabel 1, pemeriksaan nilai sebar adukan beton, pembuatan silinder beton, pengeringan, perawatan, penimbangan dan perendaman beton dan pengujian.

Tabel 1. Komposisi Campuran Beton

\begin{tabular}{|c|c|c|c|c|c|c|}
\hline & $\begin{array}{c}\text { Semen } \\
\text { Sample Uji }\end{array}$ & $\begin{array}{c}\text { Pasir } \\
(\mathrm{gram})\end{array}$ & $\begin{array}{c}\text { Air } \\
(\mathrm{gram})\end{array}$ & $\begin{array}{c}\text { Batu split } \\
\text { kecil }(\mathrm{gram})\end{array}$ & $\begin{array}{c}\text { Abu Batok } \\
\text { Kelapa } \\
(\mathrm{gram})\end{array}$ & $\begin{array}{c}\text { Abu Batok } \\
\text { Kelapa } \\
(\% \mathrm{~b} / \mathrm{b})\end{array}$ \\
\hline Beton Normal & 25 & 15 & 1,9 & 5 & 0 & 0 \\
\hline Beton abk 3 gram & 25 & 15 & 1,9 & 5 & 3 & 6 \\
\hline Beton abk 5 gram & 25 & 15 & 1,9 & 5 & 5 & 9,6 \\
\hline Beton abk 7 gram & 25 & 15 & 1,9 & 5 & 7 & 13 \\
\hline Beton abk 9 gram & 25 & 15 & 1,9 & 5 & 9 & 16 \\
\hline Beton abk 11 gram & 25 & 15 & 1,9 & 5 & 11 & 19 \\
\hline
\end{tabular}

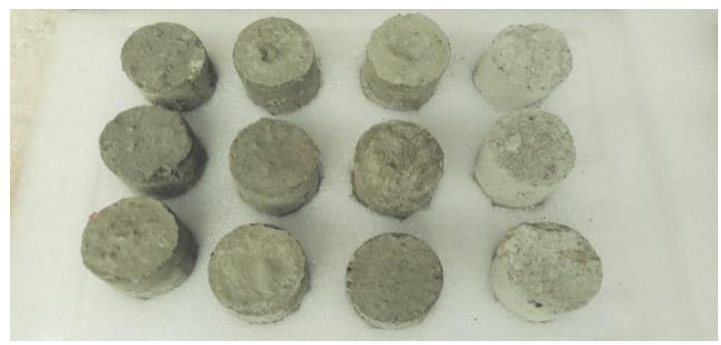

Gambar 2. Variasi Benda Uji Beton

Pengujian beton campuran meliputi uji daya serap air, uji kuat tekan dan uji kekerasan. Uji daya serap air dilakukan dengan perendaman selama 24 jam dan bahan uji dibungkus dengan kain majun agar penyerapan air oleh bahan uji beton menyerap secara sempurna. Bahan uji ditimbang sebelum dan setelah perendaman. Uji kuat tekan dilakukan dengan alat 
Compression testing machine, uji ini dilakukan untuk mengetahui daya kuat beton setelah proses pengeringan 21 hari. Sebelum dilakukan pengujian permukaan beton rata. Hal ini disebabkan karena kekasaran permukaan beton berpengaruh terhadap kekuatan beton [6]. Pengujian kuat tekan ini dilakukan dengan cara meletakkan material atau object yang akan diuji pada mesin uji, Setting compression testing machine, Sebelum pengujian dilakukan, atur kembali object peletakan benda uji, lalu tekan tuas pada mesin alat uji. Setelah pengujian dimulai, penekanan pada object akan dilakukan oleh mesin, lalu hasil dari beban yang ditekan akan muncul pada alat ukur uji tekan mesin apabila object sudah mengalami kerusakan atau retakan. Setelah pengujian telah dilakukan hasil dari seluruh analisa yang dilakukan dapat diketahui.

Uji kekerasan beton dengan alat durometer, dilakukan dengan menyalakan alat durometer dengan menekan tombol on, menempelkan nozzle pada bagian permukaan beton, memberikan beban 800 gram pada alat durometer, diamkan sebentar dan nilai kekerasan akan terlihat pada display monitor alat durometer, mengulangi pengujian di 5 titik berbeda pemukaan beton, Setelah pengujian telah dilakukan hasil dari seluruh analisa yang dilakukan dapat diketahui.

\section{HASIL DAN PEMBAHASAN}

Pengujian beton campuran batok kelapa meliputi daya serap air, kuat tekan dan kekerasan. Pada pengujian daya serap beton normal dan beton campuran diperoleh hasil sebagai grafik di bawah ini

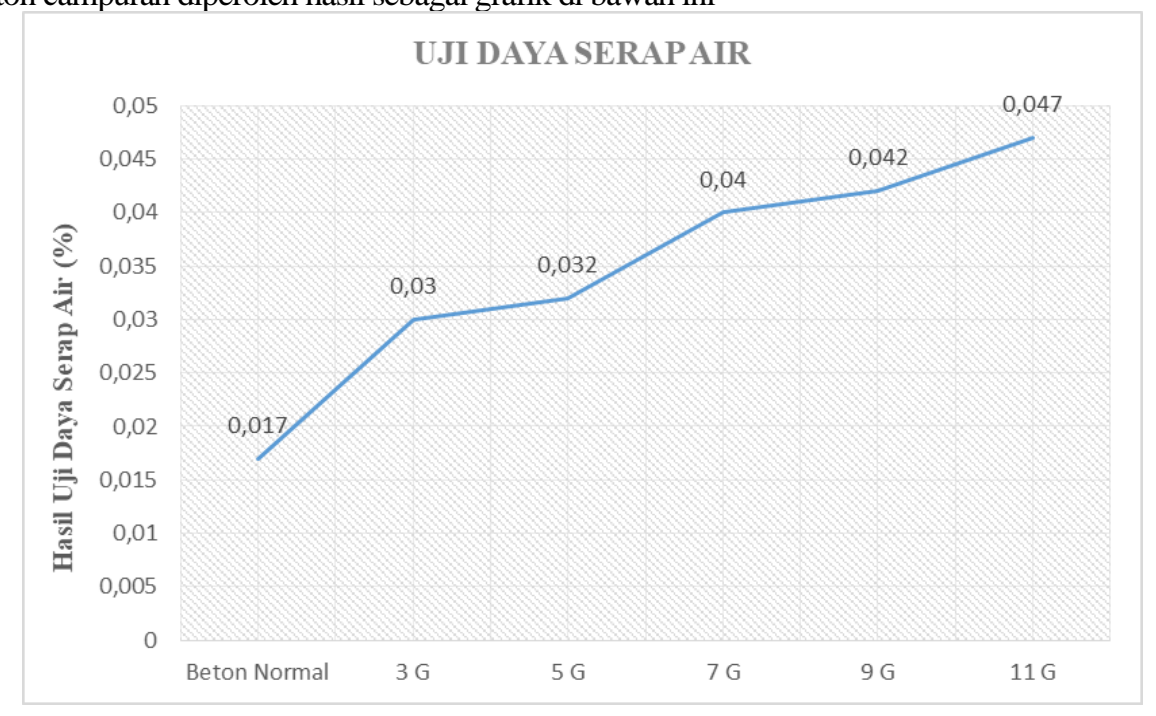

Gambar 1. Grafik daya serap air beton

Dari grafik 1. diatas dapat dilihat bahwa dengan penambahan abu batok kelapa pada campuran pembuatan beton komposisi 3 gram, 5 gram, 7 gram, 9 gram dan 11 gram dari berat agregat yang digunakan kesemuanya mengalami peningkatan dibandingkan dengan beton normal. Semakin banyak campuran abu batok kelapa pada pembuatan beton daya serap air semakin meningkat. Dan daya serap optimal pada campuran 11 gram dengan daya serap meningkat 2,7 kali lipat dibandingkan beton normal. Hal ini disebabkan karena abu batok kelapa dalam bentuk halus bereaksi dengan kapur bebas $\mathrm{Ca}(\mathrm{OH}) 2$ dan air menjadi suatu massa padat yang tidak larut di dalam air yaitu CSH dan CAH [7].

Reaksi senyawa semen dengan air membentuk senyawa $\mathrm{CSH}$ dan $\mathrm{Ca}(\mathrm{OH}) 2$ yang kemudian senyawa $\mathrm{Ca}(\mathrm{OH}) 2$ bereaksi dengan abu batok kelapa membentuk CSH dan $\mathrm{CAH}$. Reaksi senyawa semen dengan air sebagai berikut :

$$
\begin{aligned}
& \mathrm{C}_{3} \mathrm{~S}+\mathrm{H}_{2} \mathrm{O} \rightarrow \mathrm{CSH}+\mathrm{Ca}(\mathrm{OH})_{2} \\
& \mathrm{C}_{2} \mathrm{~S}+\mathrm{H}_{2} \mathrm{O} \rightarrow \mathrm{CSH}+\mathrm{Ca}(\mathrm{OH})_{2}
\end{aligned}
$$

Hasil $\mathrm{Ca}(\mathrm{OH}) 2$ dari reaksi diatas merupakan hasil sampingan dari reksi hidrasi, bereaksi kembali dengan unsur $\mathrm{SiO} 2$ dan Al2O3 dari abu batok kelapa untuk mendapatkan CSH yang kebih banyak dan CAH. Reaksi abu batok kelapa terhadap $\mathrm{Ca}(\mathrm{OH}) 2$ dapat dilihat pada reaksi dibawah ini:

$$
\begin{aligned}
\mathrm{Ca}(\mathrm{OH})_{2}+\mathrm{H}_{2} \mathrm{O}+\mathrm{SiO}_{2} & \rightarrow \mathrm{CSH} \\
\mathrm{Ca}(\mathrm{OH})_{2}+\mathrm{H}_{2} \mathrm{O}+\mathrm{Al}_{2} \mathrm{O}_{3} & \rightarrow \mathrm{CAH}
\end{aligned}
$$




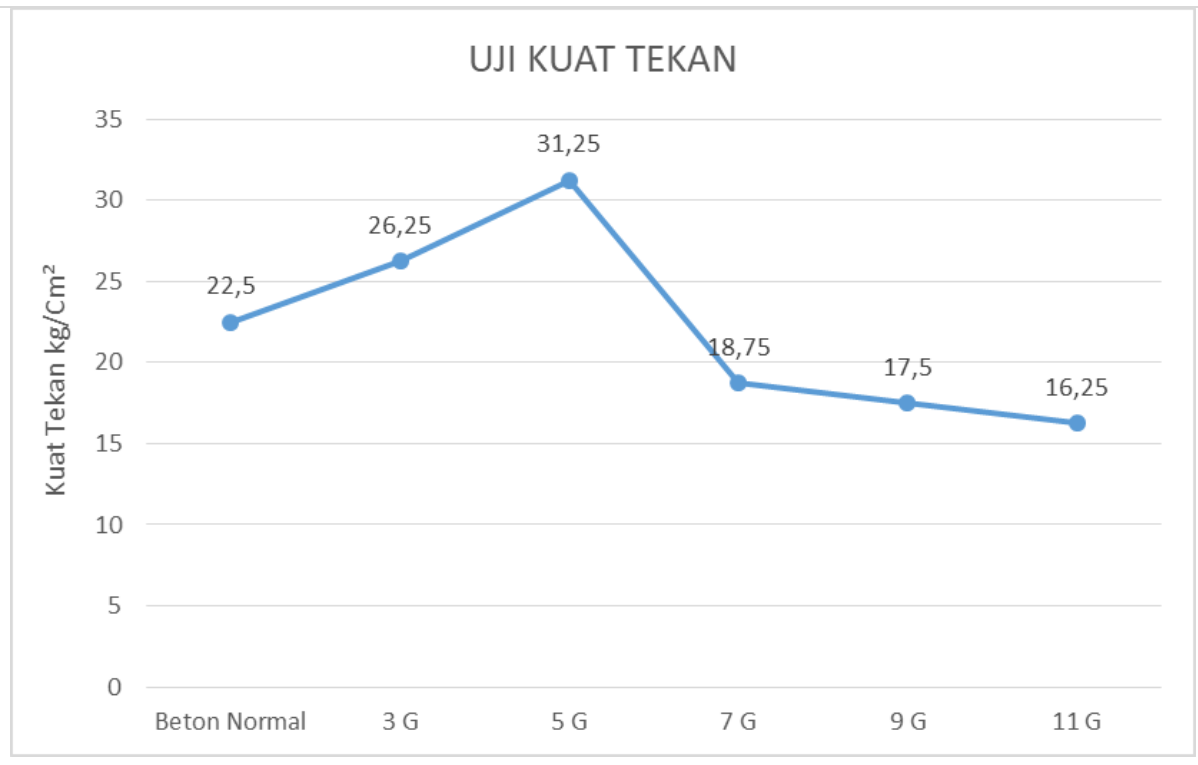

Grafik 2. Hasil Kuat Tekan Beton

Berdasarkan Grafik 2. diatas diperoleh bahwa setiap sampel baik beton normal dan beton komposisi abu batok kelapa memiliki data yang berbeda-beda. Pada proses pencampuran komposisi beton terjadi reaksi kimia yang pada umumnya bersifat hidrasi dan menghasilkan suatu pengerasan dan pertambahan kekuatan [8]. Dengan adanya campuran abu batok kelapa kuat tekan beton meningkat sampai pada campuran abu batok sebanyak 5 gram, namun pada campuran abu batok lebih banyak kuat tekan menurun. Penurunan ini menandakan bahwa semakin banyak porsentase penambahan abu batok kelapa diatas 5 gram maka nilai kuat tekannya semakin menurun. Penurunan ini terjadi karena semakin banyak campuran abu batok kelapa sehingga tidak mampu diikat oleh semen (kapur bebas $\mathrm{Ca}(\mathrm{OH})_{2}$ ). Reaksi antara kapur, air dan silika dapat dilihat di bawah ini:

$\mathrm{Ca}(\mathrm{OH})_{2}+\mathrm{H}_{2} \mathrm{O}+\mathrm{SiO}_{2} \rightarrow \mathrm{CSH}$

Dengan adanya senyawa CSH ini dapat meningkatkan kekuatan campuran beton.

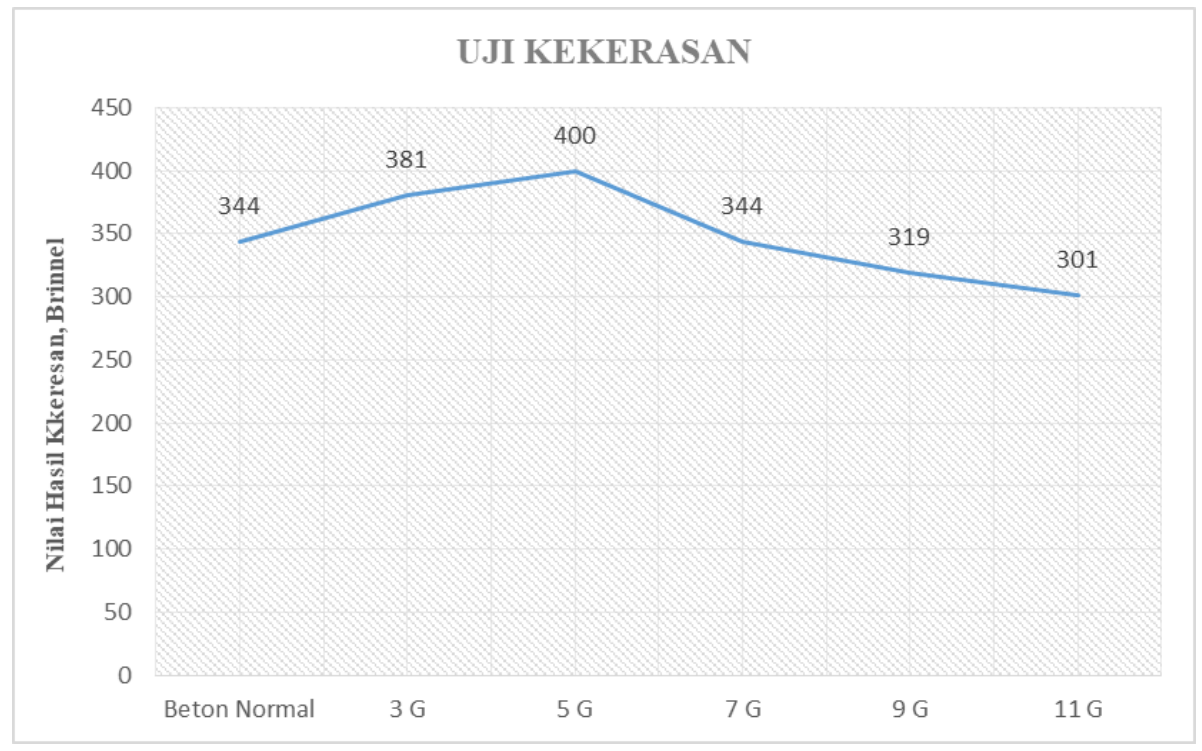

Grafik 3. Hasil Uji Kekerasan Beton

Berdasarkan Grafik 3 diperoleh bahwa dengan adanya campuran abu batok kelapa kekerasan beton meningkat sampai pada campuran abu batok sebanyak 5 gram, namun pada campuran abu batok lebih banyak kuat tekan menurun. Kekerasan beton optimal pada abu batok kelapa 5 gram dengan nilai kekerasan 400 Brinnel. Hasil ini berbanding lurus dengan hasil uji 
Jurnal Teknik Mesin: CAKRAM 2021

Fifit Astuti, Alifuddin Al Irfan, Pengaruh Penambahan Campuran Abu Batok Kelapa Terhadap Kuat Tekan, Kekerasan dan Daya Serap Air Pada Pembuatan Beton

kuat tekan pada beton yaitu kuat tekan optimal pada campuran batok sebanyak 5 gram. Hal ini sesuai dengan teori bahwa kekerasan berbanding lurus dengan kuat tekan material.

\section{KESIMPULAN}

1. Pada pengujian daya serap air beton diperoleh semakin tinggi kandungan abu batok kelapa pada beton maka daya serap air semakin meningkat. Hal ini disebabkan karena abu batok kelapa bersifat pazzolan karena mengandung silika.

2. Pada pengujian uji kuat tekan pada beton diperoleh semakin tinggi kandungan abu batok kelapa maka kuat tekan beton semakin meningkat dan optimal pada kandungan batok kelapa 5 gram dengan nilai kuat beton rata-rata $31,25 \mathrm{~kg} / \mathrm{cm}^{2}$ sedangkan beton tanpa campuran abu batok kelapa memperoleh nilai rata-rata $22,5 \mathrm{~kg} / \mathrm{cm}^{2}$.

3. Pada pengujian uji kekerasan diperoleh semakin tinggu kandungan abu batok kelapa maka kekerasannya meningkat dan mendapatkan nilai tertinggi pada beton campuran abu batok kelapa 5 gram dengan 400 Brinnel. Hasil ini berbanding lurus dengan hasil uji tekan pada beton, semakin keras beton makan uji tekan nya juga akan semakin kuat.

\section{DAFTAR PUSTAKA}

[1] Sagel, R, Isole, P dan Kusuma, G, 1994. Pedoman Pengerjaan Beton Berdasarkan SKSNI T-15-1991-33. Cetakan Keempat, Erlangga, Jakarata

[2] Eva Fitriani dan Harso Kurniawan, 2020, Konsumsi Semen Melonjak, diakses pada tanggal 27 Maret 2021 di https://investor.id/business/konsumsi-semen-melonjak

[3] Aprianti, Evi, Payam, Shafigh, Syamsul, Bahri, and Javad, Nodeh Farahani., 2015, Supplementary Cementitious Materials Origin from Agricultural Wastes- A Review, Construction and Building Materials 74 (April): 176-87

[4] Alamsyah, Andi Nur, 2005. Virgin coconut oil. Agro media pustaka, Jakarta

[5] Vignesh Kumar, Aruna devi, Manohari, Maria santha. 2014. Experimental Study on Partial Replacement of Cement with Coconut Shell ash in Concrete. International Journal of Science and Research. Virudhunagar, India

[6] Sujatmiko, Bambang. 2019. Teknologi Beton dan Bahan Bangunan. Media Sahabat Cendikia, Jakarta

[7] Tri, Mulyono. 2006. Teknologi Beton. Andi Offset, Yogyakarta

[8] Mulyati, S., Dahlan, D., \& Adril, E. (2012).Pengaruh Persen Massa Hasil Pembakaran Serbuk Kayu dan Ampas Tebu Pada Mortar Terhadap Sifat Mekanik dan Sifat Fisisnya,4(1), 31-39 